\title{
INTERVENSI BERBASIS SEKOLAH SEBAGAI PENGEMBANGAN PROGRAM BUKU HARIAN ANAK TERHEBAT
}

[Afifah Nasyahta Dila]

\section{INTRODUCTION}

Buku Harian Anak "Terhebat" (Terbiasa Hidup Bersih dan Sehat) atau BHAT merupakan buku harian yang harus diisi siswa kelas 4 dan 5 SD tentang PHBS harian di rumah, tabel konsumsi anak harian dan pada akhir buku berisi tentang PHBS mingguan di rumah. Sejak diluncurkan pada bulan Agustus 2016, berikut capaian indikator PHBS di tingkat Sekolah Dasar pada tahun 2017

Capaian PHBS 2017 pada tingkat SD -2016 =2017 -Target

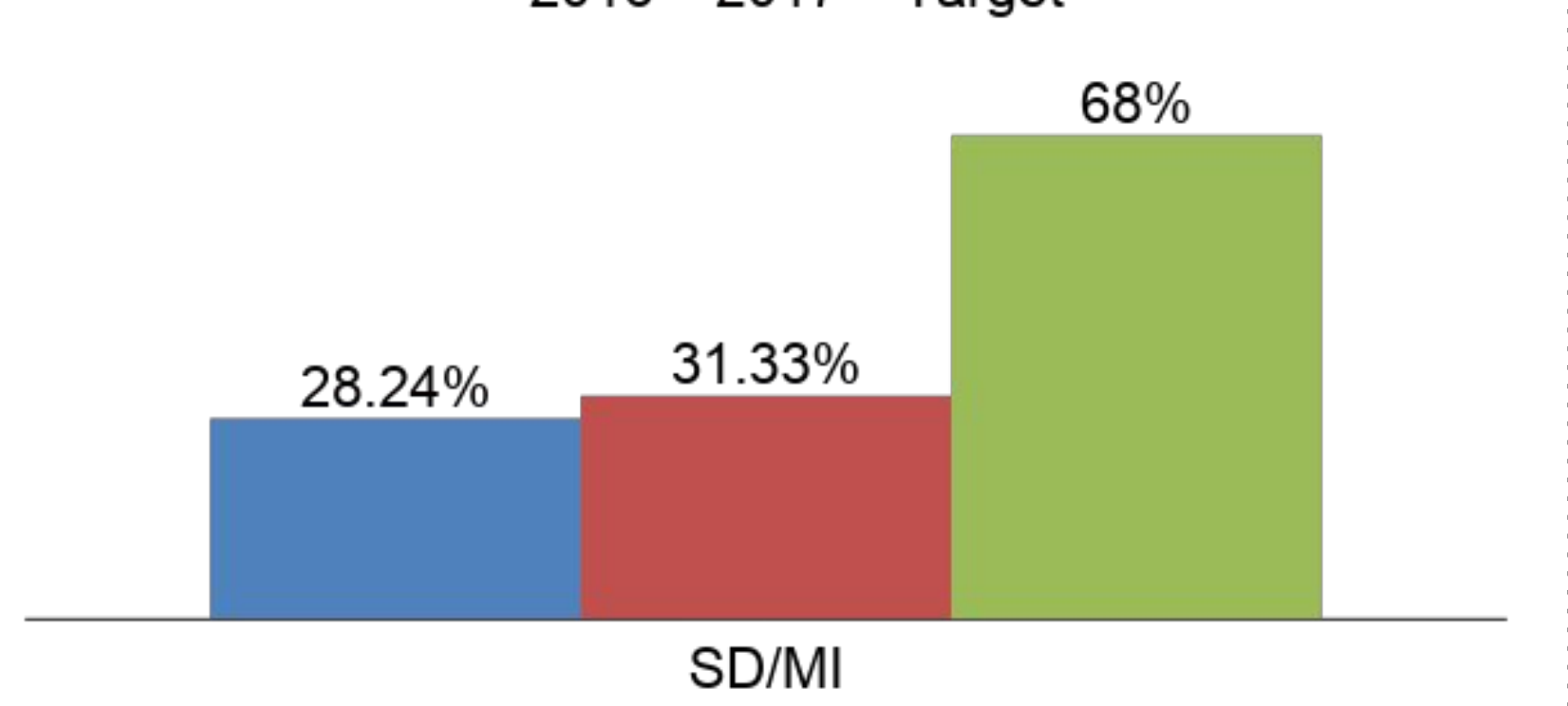

Berdasarkan rekapitulasi laporan BHAT dari seluruh SD yang terlibat didapatkan beberapa masalah PHBS di tingkat Sekolah Dasar pada tahun 2017 yaitu :

1. Belum tersedianya jajanan sehat di sekolah

2. Masih ditemukan anak SD yang merokok

3. Rendahnya kesadaran untuk melakukan CTPS
AIMS

Untuk mempertahankan sustainbilitas program BHAT dan meningkatkan peran sekolah dalam menerapkan kebiasaan hidup bersih dan sehat

\section{METHODS}

Studi kasus menggunakan pendekatan kualitatif dan studi literatur. Data diperoleh dari observasi laporan BHAT dan wawancara pemegang program.

Berdasarkan observasi laporan BHAT dan wawancara pemegang program, kendala keberlangsungan program yaitu:

1. Laporan BHAT setiap SD diunggah secara online ke dalam rekapitulasi laporan yang tersedia di blog propemaslumajang. Namun sulit untuk dipahami hasil dari kegiatan BHAT.
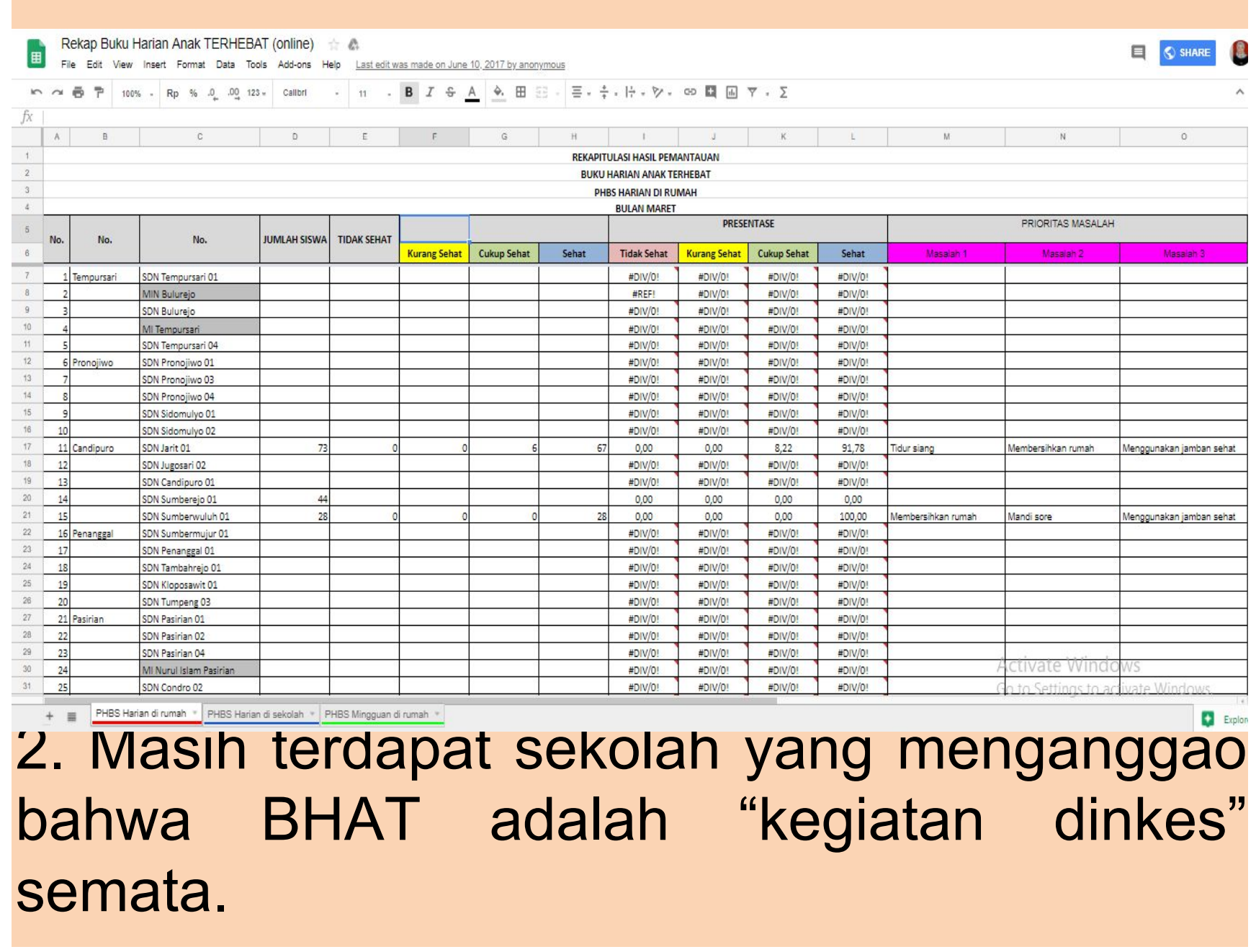

\section{RESULTS}

Intervensi berbasis sekolah merupakan kegiatan kesehatan yang pelaksanaannya dilimpahkan ke pihak sekolah. Kegiatan in merupakan bentuk tindak lanjut program BHA dan sekaligus integrasi kegiatan UKS. Dasa yang digunakan dalam merancang kegiatan kesehatan di sekolah yaitu laporan BHAT.

Langkah-langkah yang dapat ditempuh Dinas Kesehatan Kabupaten Lumajang dalam implementasi kegiatan intervensi berbasis sekolah yaitu :

Lobbying Bupati dan lintas sektor untuk mendukung integrasi BHAT dan UKS dalam intervasi berbasis sekolah

$$
\text { Puskesm }
$$

Negoisasi dengan Puskesmas dan Sekolah dalam merancang kegiatan dan anggaran serta mendeskripsikan tupoksi masing-masing sektor

Memberikan capacity building bagi petugas UKS atau guru

Merumuskan kebijakan terkait implementasi intervensi berbasis sekolah di Kabupaten Lumajang

\section{CONCLUSIONS}

Intervensi berbasis sekolah merupakan strategi promosi kesehatan yang efektif untuk membentuk perilaku anak dan mempertahankan sustaibilitas program BHAT serta salah satu upaya pencapaian masyarakat yang sehat dan mandiri.

\section{REFERENCES}

Agabio, R., Trincas, G., Floris, F., Mura, G., Sancassiani F., \& Angermeyer, M. C. (2015). A systematic review of school-based alcohol and other drug prevention programs. Clinical practice and epidemiology in menta health: CP \& EMH, 11(Suppl $1 \mathrm{M6}$ ), 102

Lai, S.K Costigan, S.A Morgan, P.J, Lubans, D.R Stodden, D.F., Salmon, J. and Barnett, L.M., 2014. Do school-based interventions focusing on physical activity fitness, or fundamental movement skill competency produce a sustained impact in these outcomes in children and adolescents? A systematic review of follow-up studies. Sports Medicine, 44(1), pp.67-79.

Langford, R., Bonell, C., Jones, H., Pouliou, T., Murphy, S Waters, E., Komro, K., Gibbs, L., Magnus, D. and Campbell, R., 2015. The World Health Organization's Health Promoting Schools framework: a Cochrane systematic review and meta-analysis. BMC public health, 15(1), p.130.

Racey, M., O'Brien, C., Douglas, S., Marquez, O., Hendrie G. and Newton, G., 2016. Systematic Review of School-Based Interventions to Modify Dietary Behavior: Does Intervention Intensity Impact Effectiveness? Journal of School Health, 86(6), pp.452-463 